\title{
ASSESSMENT AND ZONING OF RECREATIONAL FACILITIES NORTH KAZAKHSTAN REGION FOR THE DEVELOPMENT OF THE TOURISM INDUSTRY
}

\author{
Pavel S. DMITRIYEV \\ North Kazakhstan Kozybayev University, Faculty of Geography and Ecology, \\ Petropavlovsk, Republic of Kazakhstan, e-mail: dmitriev_pavel@mail.ru
}

Ivan A. FOMIN

Tyumen State University, Faculty of Geoecology and Nature Management, Institute of Geosciences, Tyumen, Russian Federation and North Kazakhstan Kozybayev University, Faculty of Geography and Ecology, Petropavlovsk, Republic of Kazakhstan, e-mail: iafomin@mail.ru

\section{Jan A. WENDT ${ }^{*}$}

University of Gdańsk, Faculty of Social Sciences, Institute of Socio-Economic

Geography and Spatial Management, Gdańsk, Poland, e-mail: jan.wendt@ug.edu.pl

\begin{abstract}
Citation: Dmitriyev, P.S., Fomin I.A., \& Wendt, J.A. (2021). ASSESSMENT AND ZONING OF RECREATIONAL FACILITIES NORTH KAZAKHSTAN REGION FOR THE DEVELOPMENT OF THE TOURISM INDUSTRY. GeoJournal of Tourism and Geosites, 38(4), 1069-1075. https://doi.org/10.30892/gtg.38411-745
\end{abstract}

\begin{abstract}
The publication is devoted to the study and classification of zoning of recreational facilities for their possible use and development of the tourism industry in the North Kazakhstan region of the Republic of Kazakhstan. The obtained data characterizing natural and recreational objects, allowing to create a picture of their spatial placement, by the administrati ve districts of the region, are studied. The conducted study of recreational facilities allowed them to be zoned. These aspects allowed us to determine the degree of their demand, to identify objects already used or recommended for use as objects in the tourism industry. A cartographic material has been prepared that visually reflects the opportunities, problems and prospects for the development of the tourism industry in the region In the studied territory, recreational objects are identified, which, according to a number of similar features, we combine into five types: natural, natural-technical, architectural, historical-revolutionary, archaeological. The natural territories of the North Kazakhstan region considered by us were united into five recreational districts.
\end{abstract}

Key words: recreational facilities, landscape, natural objects, natural monuments, tourism industry, zoning

$* \quad * \quad * \quad * *$

\section{INTRODUCTION}

The recreational system is social in nature, since its central object is a person, and its main purpose is the physical and spiritual improvement of people (Abubakirova et al., 2016). The uniqueness of natural objects creates the economic basis of the region and includes moral and aesthetic aspects that are an integral part of the formation of the culture of citizens (Kuralbayev et al., 2016). This is reflected in the program documents: "Cultural Heritage", which includes a number of large-scale projects that are being implemented at the state level (Zhidkoblinova, 2013; Bancerova et al., 2018; Ismagulova et al., 2020; Wendt, 2020). Such programs are typical not only for Kazakhstan, but for other regions as well (Więckowski and Saarinen, 2019; Cerić and Więckowski, 2020). The authenticity of Kazakhstan is of particular interest for the formation of the image and development of the tourism industry in the state (Kantarci, 2007a; 2007b; 2007c; Shakirova, 2015).

A comprehensive study of natural and recreational, cultural and historical objects at the state level allows: firstly, the creation of an integral system for studying the vast and often endangered cultural heritage of the people (Ilieș et al., 2020), including modern national culture, folklore, traditions and customs (Smykova, 2015; Saparov et al., 2017). Secondly, it allows you to study natural objects for their further preservation and rational use for the development of economic potential, aesthetic perception, for emphasis on the uniqueness of the region (Aimagambetov et al., 2017; Batyrova et al., 2018). Third, it allows for the reconstruction of significant historical, cultural and architectural monuments of particular importance for national history, where environmental objects act as an integral part of it (Tiberghien et al., 2017; Tiberghien and Xie, 2018; Tiberghien et al., 2018; Tiberghien, 2019). Thus, the uniqueness of natural objects and the historical and cultural heritage of the territory of the North Kazakhstan region is the basis for the development of recreational potential, for the formation of the tourism industry in the regional and local level (Fomin et al., 2020; Morar et al., 2020; Dmitriyev et al., 2021). Numerous studies are devoted to the study of recreational facilities of the North Kazakhstan region and the city of Petropavlovsk. As a result of the research, it was revealed that these include objects of natural, natural-technical and anthropogenic origin (Vodopyanova, 1985; Beletskaya, 1987).

\footnotetext{
${ }^{*}$ Corresponding author
} 
Natural and recreational objects of the region are a place of rest and recuperation, others have scientific and educational significance, and still others serve as the main economy (reservoirs, artificial coniferous forests, etc.) (Creswell, 2003).

The development of ecological tourism based on natural and recreational facilities will allow, while maintaining a healthy ecological environment, to develop the economic potential of the region (Tiberghien, 2019; Dmitriyev et al., 2021). A systematic study of recreational facilities will allow us to study the dynamics under the influence of an anthropogenic factor. The importance of the current state of recreational facilities will help to identify existing problems, help to maintain them in good condition for sustainable development (Zhakupov et al., 2015; Deac et al., 2018; Tleubayeva, 2018; Wendt et al., 2021a). In addition, to create a holistic representation of the placement of recreational objects, their systematization and spatial zoning are necessary.

For all regions, including Northern Kazakhstan, it is very important to solve a number of tasks when studying recreational facilities. Among them, the study of the current state, spatial placement, transport accessibility, classification and zoning (Page, 2004; Michniak et al., 2015; Chernova and Sukhova, 2017; Stoica et al., 2017; Dmitriyev et al., 2021). An integral part is the study of the possibility of their use for various purposes - tourism, excursions, scientific research, economics, etc. The solution of one of the important tasks will determine the degree of demand for recreational facilities in the tourism industry, in the education system and other industries. The study and use of recreational facilities is based on the sustainable development of the territory (Nazarova et al., 2019; Nazarova et al., 2020; Wendt at al., 2021b).

\section{MATERIALS AND METHODS}

The research included the collection of field data, the study of accumulated material, including archival material. As part of the study, the method of visual observations, the cartographic method, and work with stock material were used. The theoretical methods included a comparative analysis of the data.

a) research and observations, a survey of the population, a geographical description using cartographic, comparativegeographical, historical-geographical, etc. were carried out methods;

b) the analysis of the current state of natural and recreational objects of the studied territory, for the development of the tourism industry, to identify their potential opportunities, is carried out.

c) an attempt has been made to classify and zoning recreational objects of the studied territory.

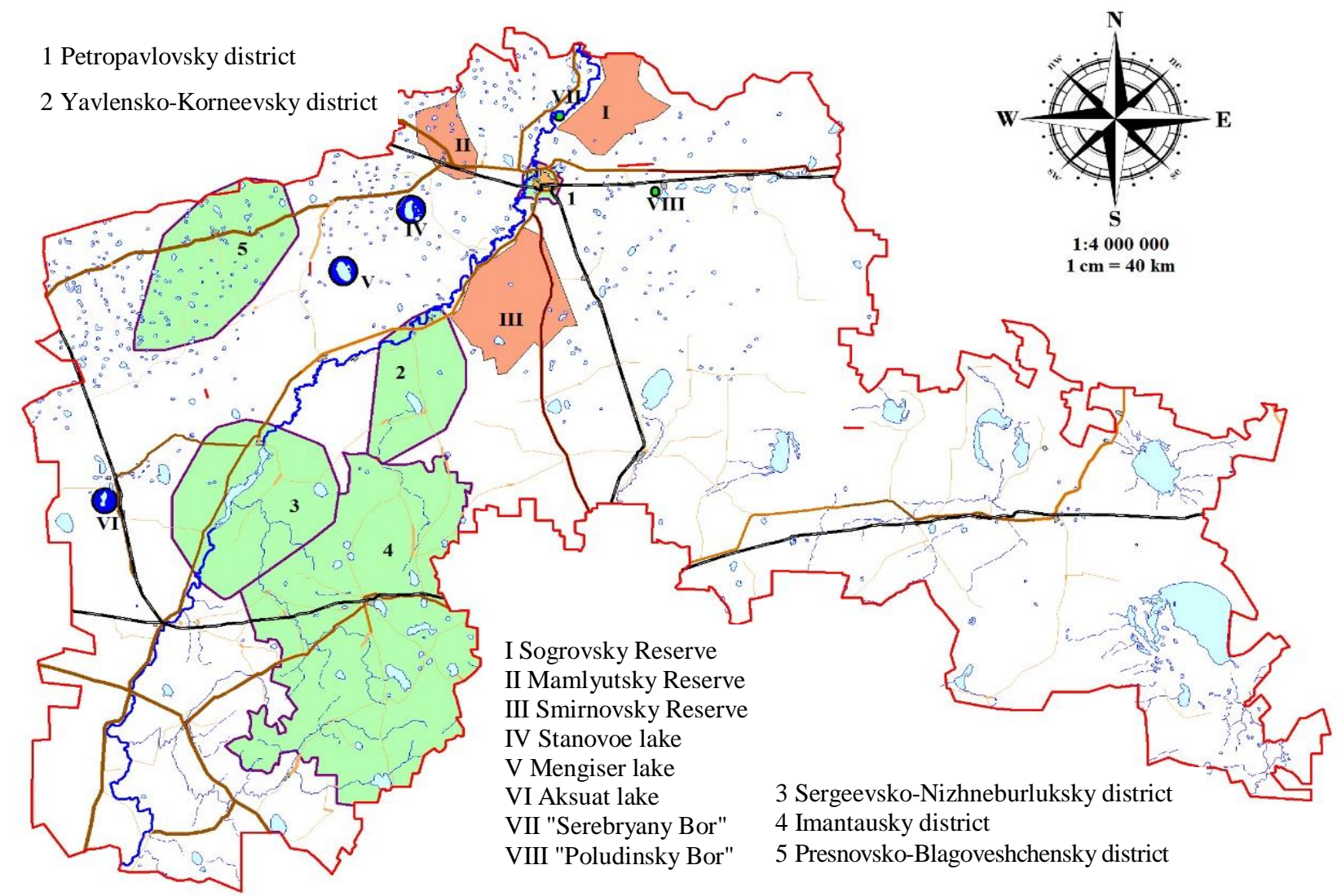

Figure 1. Distribution of recreational areas and recreational facilities on the territory of the North Kazakhstan region (Source: own elaboration)

The publication presents the results of field research, methods of statistical processing, mathematical analysis and study of satellite images. There are a large number of classifications for determining tourist zoning. However, on the basis of local history material and scientific data, we have made an attempt to develop a classification and zoning of recreational objects of the studied territory. This allowed us to distinguish 5 types: natural, natural-technical, architectural, historicalrevolutionary and archaeological. In this publication, the natural type of recreational objects is considered. According to zoning, we have identified five recreational areas: Petropavlovsky, Yavlensko-Korneevsky, Sergeevsko- 
Nizhneburluksky, Presnovsko-Blagoveshchensky and Imantausky, single recreational facilities were combined separately. The factors determining a particular recreational area were taken as the basis used by us in assessing the recreational potential. When analyzing the properties of recreational objects, the main factors characterizing their tourist and recreational potential are determined. To assess the level of recreational potential of each recreational area, we used a complex quality indicator calculated by the weighted average calculation method. Based on this methodology and the available scientific materials and the results of a sociological survey, coefficients were calculated that made it possible to assess the properties of a recreational object in order to calculate its potential. In addition, after the allocation of recreational areas in the territory of the North Kazakhstan region, an assessment of their recreational potential is given.

$$
k=\sum k_{i} \sum a_{i} \quad \text { (Gubij et al., 2005) }
$$

where $k_{i}$ - indicator $i$ - object properties, points; $a_{i}$ - coefficient of weighting of indicators $k_{i}$, fractions of a unit $\left(\sum a_{i}=1\right)$

\section{RESULTS AND DISCUSSION}

The choice of territories and objects for recreational purposes may well be engaged in the branches of physical geography - geomorphology, hydrology, climatology, etc. The nature around us is in continuous change, which is expressed in the change of physical and geographical conditions and the evolution of the organic world. The events of the past have left their mark on the appearance of the relief, in the composition and structural features of the rocks and the fossils contained in them (this is how the remains of extinct animals and plants show).

That is why some landforms, rocks and finds of extinct animals and plants serve as a kind of pages of the great stone chronicle of the Earth. On the one hand, very characteristic or rare landforms, rocks and fossils found in a particular territory are monuments of the geological past of the planet, and on the other hand, they are the most important recreational resources. There are more than twenty-five such monuments of the geological past within the borders of the North Kazakhstan region, the study of which allows us to collect information about events and landscapes that took place in the Petropavlovsk Priishimye many millions of years ago. Based on the studied material, an assessment of the level of recreational potential of each recreational area was given, based on a modified complex quality indicator obtained by the weighted average calculation method, according to 11 criteria, according to a 5-point system. This made it possible to present the studied material in the form of a table (Table 1).

Table 1. Assessment of the properties of a recreational object (Source: the authors' own calculations)

\begin{tabular}{|c|c|c|c|c|c|c|}
\hline \multirow{2}{*}{$\begin{array}{l}\text { A property of a } \\
\text { recreational object }\end{array}$} & \multicolumn{5}{|c|}{$\begin{array}{l}\text { Quantitative characteristics of the parameter of the } \\
\text { indicator of the property of the object (ki), score }\end{array}$} & \multirow{2}{*}{$\begin{array}{c}\text { The } \\
\text { weighting } \\
\text { coefficient } \\
\text { of the } \\
\text { indicator }\left(\mathrm{a}_{\mathrm{i}}\right)\end{array}$} \\
\hline & 1 & 2 & 3 & 4 & 5 & \\
\hline $\begin{array}{l}\text { Availability of } \\
\text { transport } \\
\text { infrastructure }\end{array}$ & $\begin{array}{l}\text { Lack of roads } \\
\text { with a good } \\
\text { surface }\end{array}$ & $\begin{array}{l}\text { Poor provision of } \\
\text { roads }\end{array}$ & $\begin{array}{l}\text { The presence of } \\
\text { roads of regional } \\
\text { significance }\end{array}$ & $\begin{array}{l}\text { Availability of } \\
\text { roads of national } \\
\text { significance }\end{array}$ & $\begin{array}{c}\text { Good provision of } \\
\text { transport } \\
\text { infrastructure }\end{array}$ & 0.07 \\
\hline $\begin{array}{l}\text { Geomorphological } \\
\text { objects }\end{array}$ & $\begin{array}{c}\text { Absence of } \\
\text { geomorphological } \\
\text { objects }\end{array}$ & $\begin{array}{c}\text { Ordinary } \\
\text { geomorphological } \\
\text { objects }\end{array}$ & $\begin{array}{c}\text { More significant } \\
\text { geomorphological } \\
\text { objects }\end{array}$ & $\begin{array}{l}\text { Geomorphological } \\
\text { objects of } \\
\text { significant value }\end{array}$ & $\begin{array}{c}\text { Geomorphological } \\
\text { objects protected } \\
\text { by law }\end{array}$ & 0.10 \\
\hline $\begin{array}{l}\text { Natural } \\
\text { monuments }\end{array}$ & Lack of attractions & $\begin{array}{l}\text { Ordinary natural } \\
\text { objects }\end{array}$ & $\begin{array}{c}\text { More significant } \\
\text { natural } \\
\text { monuments }\end{array}$ & $\begin{array}{c}\text { Natural monuments } \\
\text { of conside-rable } \\
\text { value }\end{array}$ & $\begin{array}{c}\text { Natural monuments } \\
\text { protected by law }\end{array}$ & 0.15 \\
\hline $\begin{array}{l}\text { Significant natural } \\
\text { and recreational } \\
\text { hydrological objects }\end{array}$ & $\begin{array}{l}\text { With visible } \\
\text { contamina-tion }\end{array}$ & $\begin{array}{l}\text { With the } \\
\text { content of odors }\end{array}$ & $\begin{array}{l}\text { Within the } \\
\text { normal range }\end{array}$ & $\begin{array}{l}\text { Within the normal } \\
\text { limits for drinking } \\
\text { water supply }\end{array}$ & $\begin{array}{l}\text { Exceptionally clean } \\
\text { reser-voirs with } \\
\text { spring nutrition }\end{array}$ & 0.15 \\
\hline Botanical objects & $\begin{array}{l}\text { Swampy with } \\
\text { rare shrubs }\end{array}$ & $\begin{array}{l}\text { Small woodlands } \\
\text { and spruce forests }\end{array}$ & $\begin{array}{c}\text { Meadow } \\
\text { vegetation }\end{array}$ & Mixed forest & Light pine forests & 0.10 \\
\hline $\begin{array}{l}\text { Aesthetics of } \\
\text { landscapes }\end{array}$ & $\begin{array}{c}\text { Weak } \\
\text { expressiveness of } \\
\text { the relief }\end{array}$ & $\begin{array}{l}\text { Monotonous } \\
\text { landscape }\end{array}$ & $\begin{array}{l}\text { Expressive } \\
\text { landscape }\end{array}$ & $\begin{array}{l}\text { Picturesque views } \\
\text { of the landscape }\end{array}$ & $\begin{array}{l}\text { Bright multi- } \\
\text { faceted picturesque } \\
\text { views of the } \\
\text { landscape }\end{array}$ & 0.12 \\
\hline $\begin{array}{l}\text { Anthropogenic } \\
\text { load of the } \\
\text { recreational area, } \\
\mathrm{km}^{2} / \text { person }\end{array}$ & $\begin{array}{c}\text { Availability of } \\
\text { industrial facilities }\end{array}$ & $\begin{array}{c}\text { A dense network } \\
\text { of rural } \\
\text { settlements, the } \\
\text { presence of landfills }\end{array}$ & $\begin{array}{l}\text { A large area of } \\
\text { land allocated for } \\
\text { agriculture }\end{array}$ & $\begin{array}{l}\text { The predominance } \\
\text { of protected areas } \\
\text { over those used in } \\
\text { agriculture }\end{array}$ & $\begin{array}{c}\text { A large number of } \\
\text { protected natural } \\
\text { areas }\end{array}$ & 0.08 \\
\hline Faunal diversity & $\begin{array}{l}\text { Depleted species } \\
\text { composition of } \\
\text { fauna }\end{array}$ & $\begin{array}{l}\text { Diverse species } \\
\text { composition of the } \\
\text { fauna }\end{array}$ & $\begin{array}{c}\text { Rich species } \\
\text { composition of the } \\
\text { fauna }\end{array}$ & $\begin{array}{c}\text { Rare and } \\
\text { endangered species }\end{array}$ & $\begin{array}{l}\text { Species listed in } \\
\text { the Red Book }\end{array}$ & 0.10 \\
\hline $\begin{array}{c}\text { Historical and } \\
\text { cultural monuments }\end{array}$ & Lack of attractions & $\begin{array}{c}\text { Ordinary } \\
\text { monuments }\end{array}$ & $\begin{array}{l}\text { More significant } \\
\text { monuments }\end{array}$ & $\begin{array}{c}\text { Monuments of } \\
\text { great artistic value }\end{array}$ & $\begin{array}{c}\text { Monuments } \\
\text { protected by law }\end{array}$ & 0.08 \\
\hline $\begin{array}{l}\text { The level of } \\
\text { improvement }\end{array}$ & $\begin{array}{c}\text { Minor } \\
\text { landscaping }\end{array}$ & $\begin{array}{c}\text { Additional } \\
\text { improvement of } \\
\text { beaches }\end{array}$ & $\begin{array}{l}\text { Additional food } \\
\text { outlets }\end{array}$ & Overnight stay & Capital structures & 0.05 \\
\hline
\end{tabular}


The highest coefficient of 0.15 characterizing the properties of a recreational object belongs to the presence of natural monuments and hydrological objects. In the second place - the aesthetics of landscapes, it corresponds to a coefficient of 0.12. The third place is shared by geomorphological objects, faunal diversity and botanical objects, 0.1 each. The assessment of anthropogenic load and historical and cultural monuments account for 0.08 each. It is interesting that socioeconomic properties such as the availability of transport infrastructure and the level of improvement account for -0.07 and 0.05 , respectively. Thus, it can be concluded that among the main properties of recreational facilities, much attention is paid to the natural resource potential, visual and aesthetic enjoyment of the natural environment. All this underlines the interest directly in eco-tourism, despite the development of infrastructure. All recreational objects of the studied territory are combined into five types: natural, natural-technical, architectural, historical-revolutionary and archaeological. In turn, each of them is divided into several subtypes. However, I would like to focus directly on natural and recreational facilities, as the most attractive for the development of the tourism industry in the North Kazakhstan region (Table 2).

Table 2. Taxonomic system of recreational areas (Source: the authors' own calculations)

\begin{tabular}{|c|c|c|c|}
\hline $\begin{array}{c}\text { Taxono- } \\
\text { mic rank }\end{array}$ & $\begin{array}{c}\text { Name of the } \\
\text { taxonomic unit }\end{array}$ & The order of the territory size & Example of a recreational area \\
\hline I & Recreation center & Tens or hundreds of hectares & $\begin{array}{c}\text { "Serebryany Bor", Central Park of Culture and } \\
\text { Recreation, relict Zhanazholsky Bor, }\end{array}$ \\
\hline II & Recreational microdistrict & Hundreds of $\mathrm{km}^{2}$ or thousands of hectares & Lakes: B. Tarangul, M. Tarangul, Mengiser, Zhaltyr \\
\hline III & $\begin{array}{c}\text { Recreational subdistrict } \\
\text { (mesorayon) }\end{array}$ & Thousands or hundreds of $\mathrm{km}^{2}$ & $\begin{array}{c}\text { Nature reserves: Smirnovsky, Sogrovsky, } \\
\text { Mamlyutsky }\end{array}$ \\
\hline IV & Recreational area & Hundreds or tens of thousands of $\mathrm{km}^{2}$ & Yavlensko-Korneevsky \\
\hline V & Recreational zone & Hundreds of thousands or tens of thousands of $\mathrm{km}^{2}$ & \\
\hline
\end{tabular}

The given taxonomic system of recreational areas made it possible to distinguish five taxonomic ranks based on the area indicator. Among them, the recreational zone is the actual territory of the North Kazakhstan region, and recreational areas are large areas of the territory that combine recreational objects according to the above properties.

Despite the relative monotony of the natural conditions of the North Kazakhstan region, within its limits we distinguish the following properties of recreational areas - the presence of geomorphological objects, hydrological, botanical and zoological, and also takes into account such important conditions as the area of the recreational area, the aesthetics of landscapes, the presence of historical and cultural monuments and the level of landscaping.

A recreational area is a territorial set of economically interconnected recreational enterprises specializing in the service of recreants, which allows them to best meet their needs using the existing natural and cultural-historical complexes of the territory and its economic conditions. Recreational facilities in the territory of the North Kazakhstan region are located unevenly. Some administrative districts that occupy a significant area are poor in recreational resources (Tayynshinsky, Ualikhanovsky, Akzharsky). At the same time, several types of recreational facilities can be located on a small area of administrative districts at once: Yesilsky, Zhambylsky, Shal akyn (Spravochnik, 2007).

In this regard, we have identified five recreational areas where the most recreational objects of different types are concentrated. In our work, we will define them as recreational areas (according to the taxonomic system of recreational areas Mironenko, Tverdokhlebova): Petropavlovsk district, Yavlensk-Korneevsky, Sergeevsko-Nizhneburluksky, Presnovsko-Blagoveshchensky, Imantau districts. Petropavlovsky district is represented by by recreational facilities of all types found on the territory of Petropavlovsk and its suburban area. Of the hydrological objects, these are the Ishim River, the Petropavlovsk Reservoir, a group of lakes and ponds; of the botanical ones - the green zone, the central park of culture and recreation, the park named after the 50th anniversary of October, the Pestroye and Borki forests; of the historical and revolutionary ones, the memorial of Eternal Glory, the regional museum of local lore, the Museum of Fine Arts, as well as monuments, busts and obelisks. All subtypes of architectural recreational objects marked in the region are located in Petropavlovsk. Yavlensko-Korneevsky district it is represented by geomorphological, hydrological, historical-revolutionary and architectural recreational objects of the Esil district.

This includes the Yavlenskoe outcrop, the Ishim River, the Kamysakty River, the Esil reservoir, the Tarangul Lake, Zhamankol, Kendykty, Balykty, Zhilandy, the Maltsevsky pond, the channel "Esil River-lake B. Tarangul", Pokrovsky spring, Maltsevsky broad gully, Koldarovsky broad gully, Alexandrovsky broad gully, Maltsevsky forest, birch stakes of the Yesilsky forestry, hunting and nature reserve farm "Krasny Bor", as well as the district historical and local history museum in the village of Yavlenka, monuments, busts and obelisks. The distance from the regional center to the administrative center of the village of Yavlenka is $76 \mathrm{~km}$.

Sergeevsko-Nizhneburluksky district it includes all recreational facilities of the Shal Akyn district. These include the Nizhneburluk graben, the Sergeyev reservoir, the channel "Sergeyev reservoir-lake M. Tarangul-lake Koldar", Lake M. Tarangul, Zhaltyr, juniper thickets (Afanasevka village), as well as archaeological sites of Baykar and Boganaty, etc. The distance from the regional center to the administrative center of Sergeevka is $176 \mathrm{~km}$. PresnovskoBlagoveshchensky district it is represented by geomorphological objects (manes, ridges, paleo-Sueri valley), hydrological (hundreds of lakes), botanical (relict Zhanazholsky forest) and zoological (Maybalyk, Budenovsky and Lapushkinsky sites). There are museum and memorial complexes of famous writers-I. Shukhov, S. Mukanov, G. Musrepov. The distance from the regional center to the administrative center of S. Presnovka $-140 \mathrm{~km}$.

Imantausky district it is represented by hydrological, geomorphological, botanical, zoological and historicalrevolutionary objects. These include: the hills "Obozrenie", "Relict massif", "Two brothers", "Sharp Sopka", "Split 
Sopka", "Waterfall with a cave", "Eagle Mountain", the island of Lake Imantau, "Cossack Island", the rock deposit "Pot", the Orlinogorsk nature Reserve, the memorial and literary museum of Sh. Ualikhanov, Lake Shalkar, Imantau, etc. The distance from the regional center to the administrative center of S.Saumalkol $-250 \mathrm{~km}$.

There are also areas on the territory of the region where several recreational facilities are located, located at a considerable distance from each other. These objects are not included in the 5 major recreational areas, but nevertheless, they are of great importance for recreation and the tourism industry. We did not include individual recreational facilities in recreational areas and, as a result, did not assess their recreational potential.

However, it is still important to list them. In the Kyzylzhar district "Serebryany Bor" and the Sogrovsky reserve, in the Mamlyutsky district - the Mamlyutsky Reserve, the Stanovoe and Mengiser lakes, in the Akkayinsky district - the Smirnovsky reserve, in the M. Zhumabayev district - the Poludinsky Bor, in the Timiryazevsky district-the lake Aksuat. The selected recreational areas of the territory of the North Kazakhstan region were evaluated according to 10 criteria on a 5-point system. The results of the evaluation calculations are presented in Table 3 .

Table 3. Comprehensive score assessment of the recreational potential of the selected areas (Source: based on the authors' calculations)

\begin{tabular}{|c|c|c|c|c|c|}
\hline Recreational areas & Petropavlovsky & $\begin{array}{l}\text { Yavlensky- } \\
\text { Korneevsky }\end{array}$ & $\begin{array}{c}\text { Sergeyevsko- } \\
\text { Nizhneburluksky }\end{array}$ & $\begin{array}{c}\text { Presnovsko- } \\
\text { Blagoveshchensky }\end{array}$ & Imantausky \\
\hline Availability of transport infrastructure & 5 & 4 & \begin{tabular}{l|l}
2 \\
\end{tabular} & 3 & 2 \\
\hline Geomorphological objects & 5 & 5 & 5 & 5 & 5 \\
\hline Natural monuments & 4 & 5 & 4 & 4 & 5 \\
\hline Significant natural and recreational hydrological objects & 5 & 5 & 3 & 3 & 3 \\
\hline Botanical objects & 5 & 4 & 4 & 4 & 5 \\
\hline Landscape aesthetics & 4 & 4 & 5 & 4 & 5 \\
\hline Anthropogenic load of the recreational area, $\mathrm{km}^{2} /$ person & 1 & 2 & 3 & 3 & 5 \\
\hline Faunal diversity & 3 & 3 & 3 & 4 & 3 \\
\hline Historical and cultural monuments & 5 & 3 & 3 & 3 & 4 \\
\hline The level of improvement & 5 & 1 & 1 & 1 & 4 \\
\hline Total recreational potential & 42 & 36 & 33 & 34 & 41 \\
\hline $\begin{array}{l}\text { Total } \mathrm{k} \text {, taking into account the weighting coefficient of } \\
\text { the indicator }\left(\mathrm{a}_{\mathrm{i}}\right)\end{array}$ & 4.21 & 3.92 & 3.43 & 3.53 & 4.04 \\
\hline
\end{tabular}

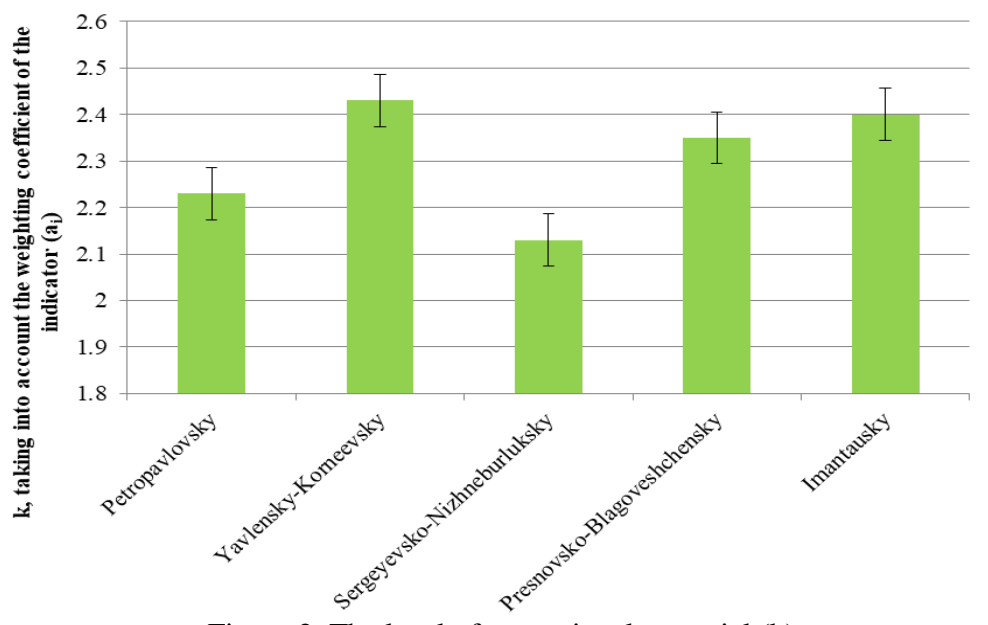

Figure 2. The level of recreational potential (k)

(Source: based on the authors' calculations)
When analyzing the table, it can be highlighted that there are no recreational areas with insignificant and low recreational potential in the territory of the North Kazakhstan region. Recreational areas with medium and high recreational potential prevail. The highest recreational potential of the studied areas is Petropavlovsk. However, according to the nature of the anthropogenic load, the Imantau recreational area still remains more attractive. This made it possible to graphically reflect the assessment of the recreational potential of the selected areas (Figure 2). Thus, the North Kazakhstan region has a high natural and recreational potential, a rich cultural heritage. All this needs careful treatment, preservation, study, etc. Problems of using recreational facilities and territories are noted. One of the main problems of the unique natural territories is the small number of staff units and the almost complete absence of researchers, tourist managers. There is a widespread lack of reliable and highly passable vehicles, which emphasizes the weak development of the road network with high-quality coverage. Excessive plowing of virgin lands and the use of pesticides and herbicides have led to a significant reduction in the number of species in the reserves. Bustard and flutter have disappeared, very few grey partridge, quail, field lark, steppe harrier remain. The situation is far from favorable with forest species of animals and birds. Poaching significantly complicates the situation in protected areas. Thus, there are many problems and the state of remarkable natural territories in the future depends on their early solution. There is an urgent need to create a forest-steppe national park in the region on the basis of the Sogrov Nature Reserve.

The first steps in this direction have been taken: the territory has been determined, the borders have been justified, natural conditions, objects, etc. have been studied. It should be noted once again that the protected areas of the region have many environmental problems. The situation is also complicated by the fact that some of the natural objects are located in densely populated places, with a very high degree of anthropogenic load. The modern tourism industry, based on the unique natural and cultural potential of the Republic of Kazakhstan, is a natural system-forming factor of flexible integration of tourism into the system of world economic relations, one of the most dynamically developing and effective in terms of return on invested capital by the industry, despite its capital intensity. 


\section{CONCLUSION}

Based on the state strategy of spiritual revival, based on knowledge about the region, it is necessary to identify the natural and recreational potential for the development of tourism in the regions of Kazakhstan. What will make the region attractive for tourists, will serve as a basis for patriotic education of citizens, for economic development.

Despite the relatively small area, the North Kazakhstan region, and especially the city of Petropavlovsk, has a large set of interesting and valuable recreational areas and objects. In the studied territory, recreational objects are identified, which, according to a number of similar features, we combine into 5 types: natural, natural-technical, architectural, historical-revolutionary, archaeological. The natural territories of the North Kazakhstan region considered by us were united into 5 recreational districts: the Petropavlovsk macro-district, the Yavlensk-Korneevsky, SergeyevskoNizhneburluksky, Presnovsko-Blagoveshchensky and Imantau districts. A significant number of recreational facilities of various types are concentrated here. On the territory of the region there are also recreational facilities located at a considerable distance, both from the regional center and from each other. We singled them out separately as single recreational objects, we did not make an assessment of their recreational potential.

The assessment of the properties of recreational facilities and designated areas allowed us to assess their potential, all this allowed us to conclude that there is a good opportunity and need for the development of eco-tourism. The information collected and summarized by us on this topic can be used by employees of organizations and institutions as reference, educational material. Systematic study of recreational facilities will allow further development of the tourism industry of the region, since tourism and recreation are currently the only areas of the economy that are really interested in preserving an ecologically healthy environment in the regions of Kazakhstan.

\section{REFERENCES}

Abubakirova, A., Syzdykova, A., Kelesbayev, D., Dandayeva, B., \& Ermankulova, R. (2016). Place of Tourism in the Economy of Kazakhstan Republic. Procedia Economics and Finance, 39, 3-6. https://doi.org/10.1016/S2212-5671(16)30232-5

Aimagambetov, E., Bugubaeva, R., Bespayeva, R., \& Tashbaev, N. (2017). Model of sustainable development of tourism industry in Kazakhstan (regional perspective). Public Policy and Administration, 16(2), 179-197. https://doi.org/10.13165/VPA-17-16-2-02

Bancerova, O.L., \& Kasimova, A.R. (2018). Formation of ethnocultural tourism clusters in Russia-Kazakhstan borderline territory. Journal of Environmental Management and Tourism, 9(4), 771-776. https://doi.org.10.14505/jemt.v9.4(28).10

Batyrova, N., Yermankulova, R., Mombekova, G., \& Jaxilikov, A. (2018). Economic problems of Kazakhstan's competitiveness in the international tourist business. Journal of Advanced Research in Law and Economics, 9(2), 396-408.

Beletskaya, N.P. (1987). Geneticheskaya klassifikaciya ozernyh kotlovin Zapadno-Sibirskoj ravniny [Genetic classification of lake basins of the West Siberian Plain]. Geomorphology, 1, 50-58, (in Russian), Accessed 25.05.2021. https://cyberleninka.ru/article/n/ geneticheskaya-klassifikatsiya-ozernyh-kotlovin-severo-kazahstanskoy-ravniny

Cerić, D., \& Więckowski, M. (2020). Establishing transboundary tourist space in the Baltic Sea region. Baltic Journal of Health and Physical Activity, 12(1), 149-157. http://doi.org/10.29359/BJHPA.12.Spec.Iss1.16

Chernova, E.O., \& Sukhova, M.G. (2017). Recreational-commercial zoning of Altai Mountains. Sustainable Development of Mountain Territories, 9(4), 362-368. https://doi.org.10.21177/1998-4502-2017-9-4-362-368

Creswell, J. (2003). Research design: Qualitative, quantitative and mixed methods approaches (2nd ed). Thousand Oaks, CA: SAGE Publications.

Deac, L.A., Gozner, M., \& Sambou, A. (2019). Ethnographic museums in the rural areas of Crișana region, Romania - keepers of local heritage, tradition and lifestyle. GeoJournal of Tourism and Geosites, 27(4), 1251-1260. http://doi.10.30892/gtg.27411-430

Dmitriyev, P.S., Fomin, I.A., Nazarova, T.V., \& Wendt, J.A. (2021). Transport accessibility of the lake ecosystems in the North Kazakhstan region as a factor of tourism development. GeoJournal of Tourism and Geosites. 35(2), 289-296. https://doi.org/10.30892/gtg.35204-650

Fomin, I., Nazarova, T., \& Baryshnikov, G. (2020). Ocenka urovnya rekreacionnogo potenciala ozernyh geosistem ravninny territorij Severnogo Kazahstana [Assessment of the level of recreational potential of the North Kazakhstan]. Problemy regional'noj ekologii, (1) (in Russian), Accessed 25.01.2021. https://doi.org.10.24411/1728-323X-2020-11088 https://www.elibrary.ru/item.asp?id=42978290

Gubij, I.G., Pavlinova, I.I., Rodin, V.N., \& Yakovlev, S.V. (2005). Kompleksnoe ispolzovanie vodnih resursov. - M. Visshaya Shkola. (in Russian), Accessed 5.10.2021. https://knigogid.ru/books/157863-kompleksnoe-ispolzovanie-vodnyh-resursov

Ilieș, D.C., Caciora, T., Herman, G.V., Ilieş, A., Ropa, M., \& Baias, Ș. (2020). Geohazards affecting cultural heritage monuments. A complex case study from Romania. GeoJournal of Tourism and Geosites, 31(3), 1103-1112. https://doi.org/10.30892/gtg.31323-546

Ismagulova, S.M., Dunets, A.N., Dmitriyev, P.S., \& Janaleyeva, K.M. (2020). Tourist relation Kazakhstan with the countries of the commonwealth of independent states at the modern stage. GeoJournal of Tourism and Geosites, 31 (3), $1146-1152$. https://doi.org/10.30892/gtg.31328-551

Kantarci, K. (2007a). The image of Central Asia countries: Kyrgyzstan, Kazakhstan, Uzbekistan and Turkmenistan. Tourism Analysis, 12(4), 307-318. https://doi.org/10.3727/108354207782212468

Kantarci, K. (2007b). Perceptions of foreign investors on the tourism market in Central Asia including Kyrgyzstan, Kazakhstan, Uzbekistan, Turkmenistan. Tourism Management, 28(3), 820-829. https://doi.org/10.1016/j.tourman.2006.05.012

Kantarci, K. (2007c). Perceptions of Central Asia travel conditions: Kyrgyzstan, Kazakhstan, Uzbekistan and Turkmenistan. Journal of Hospitality and Leisure Marketing, 15(2), 55-71. https://doi.org/10.1300/J150v15n02_04

Kuralbayev, A., Myrzaliev, B., \& Sevim, B. (2016). Organizational and economic problems in the management of the spiritual historical development of tourism in south Kazakhstan region. International Review of Management and Marketing, 6(2), $219-226$.

Michniak, D., Więckowski, M., Stẹpniak, M., \& Rosik, P. (2015). The impact of selected planned motorways and expressways on the potential accessibility of the Polish-Slovak borderland with respect to tourism development. Moravian Geographical Reports, 23(1), 13-20. https://doi.org/10.1515/mgr-2015-0002

Morar, C., Grama, V., Stupariu, I.M., Nagy, G., Boros, L., Tiba, Al., Gozner, M., \& Szabo-Alexi, S. (2020). Local perspectives over cultural tourism to heritage sites. The case study of Oradea Fortress (Romania). GeoJournal of Tourism and Geosites, 33(4), 14701479. https://doi.org/10.30892/gtg.334spl04-595 
Nazarova, T.V., Fomin, I.A., Dmitriev, P.S., Wendt, J.A., \& Janaleyeva, K.M. (2019). Landscape and limnological research of lake system of the plain areas of the northeastern borderlands of the Republic of Kazakhstan and assessment of their recreational capacity. GeoJournal of Tourism and Geosites, 25(2), 485-495. https://doi.org/10.30892/gtg.25217-375

Nazarova, T.V., Janaleyeva, G.M., Ilieș, D.C., Dmitriyev, P.S., Berdenov, Zh., \& Wendt, J.A. (2020). Research of water surface of lakes, plain territories of North Kazakhstan by using water indices. Vestnik KazNRTU, 137(1), 27-32. https://doi.org/10.51301/vest.su.2020.v137.i1.05

Page, S. (2004). Transport and Tourism. In Lew, A., Hall, C.M., Williams, A.M. (eds.), A Companion to Tourism, 146-158, Blackwell, Oxford.

Saparov, K.T., Yeginbayeva, A.Y., Nurgalieva, G.Z., Kulzhanova, S.M., Atasoy, E., \& Wendt, J.A. (2017). The question of Kazakh national and geographical toponymic as a potential factor of tourism development. Geojournal of Tourism and Geosites, 19(1), 115-125.

Shakirova, S. (2015). Country images of Kazakhstan: From stereotypes and critique to positive national branding. Journal of Eastern European and Central Asian Research, 2(1). https://doi.org.10.15549/jeecar.v2i1.78

Smykova, M. (2015). The development of a tourist brand in Kazakhstan. Journal of Eastern European and Central Asian Research, 2(2). https://doi.org.10.15549/jeecar.v2i2.74

Stoica, I.A., Hodor, N., Tudose, T., \& Coldea, G. (2017). Expected Floristic Changes in Hygro-Cryophilic and Snowbed Plant Communities Caused by Climate Change and Human Impact in The Romanian Carpathians. Contribuţii Botanice, 52, $163-181$. https://doi.org/10.24193/Contrib.Bot.52.12

Tiberghien, G. (2019). Managing the planning and development of authentic eco-cultural tourism in Kazakhstan. Tourism Planning and Development, 16(5), 494-513. https://doi.org/10.1080/21568316.2018.1501733

Tiberghien, G., \& Xie, P.F. (2018). The life cycle of authenticity: Neo-nomadic tourism culture in Kazakhstan. Journal of Tourism and Cultural Change, 16(3), 234-247. https://doi.org/10.1080/14766825.2016.1258408

Tiberghien, G., Bremner, H., \& Milne, S. (2017). Performance and visitors' perception of authenticity in eco-cultural tourism. Tourism Geographies, 19(2), 287-300. https://doi.org/10.1080/14616688.2017.1285958

Tiberghien, G., Bremner, H., \& Milne, S. (2018). Authenticating eco-cultural tourism in Kazakhstan: A supply side perspective. Journal of Ecotourism, 17(3), 306-319. https://doi.org/10.1080/14724049.2018.1502507

Tleubayeva, A. (2018). Rural tourism as one of the priority factors for sustainable development of rural territories in Kazakhstan. Journal of Environmental Management and Tourism, 9(6), 1312-1326.

Vodopyanova, S.G. (1985). Rasprostranenie, morfometriya i morfologiya ozernyh kotlovin yuzhnyh ravnin Zapadnoj Sibiri [Distribution, morphometry and morphology of lake basins of the Southern Plains of Western Siberia]. Dissertation abstract. Novosibirsk: Institute of Geology and Geophysics of the USSR Academy of Sciences, 4-11, (in Russian), (Accessed 27.05.2021). http://webirbis.spsl.nsc.ru

Wendt, J.A. (2020). Directions and area of tourism research in Kazakhstan. GeoJournal of Tourism and Geosites, 32(4), $1418-1424$. https://doi.org/10.30892/gtg.32433-589

Wendt, J.A., Pashkov, S.V., Mydłowska, E., \& Bógdał-Brzezińska, A. (2021a). Political and Historical Determinants of the Differentiation of Entrepreneurial Ecosystems of Agritourism in Poland and Kazakhstan. Sustainability, 13, 10487. https://doi.org/10.3390/su131810487

Wendt, J.A., Grama, V., Ilieş, G., Mikhaylov, A.S., Borza, S.G., Herman, G.V., \& Bógdał-Brzezińska, A. (2021b). Transport Infrastructure and Political Factors as Determinants of Tourism Development in the Cross-Border Region of Bihor and Maramureş a Comparative Analysis. Sustainability, 13, 5385. https://doi.org/10.3390/su13105385

Więckowski, M., \& Saarinen, J. (2019). Tourism transitions, changes and the creation of new spaces in Central Eastern Europe. Geographia Polonica, 92(4), 369-377. https://doi.org/10.7163/GPol.0154a

Zhakupov, A.A., Saparov, K.T., Mazbaev, O.B., Dzhanaleeva, G.M., Musabaeva, M.N., Eginbaeva, A., \& Atasoy, E. (2015). Fundamentals of recreation-geographic assessment for tourism development. Oxidation Communications, 38(3), 1539-1544.

Zhidkoblinova, O. (2013). State policy of tourism industry development in the republic of Kazakhstan. World Applied Sciences Journal, 23(8), 1079-1084. https://doi.org.10.5829/idosi.wasj.2013.23.08.13128

*** Spravochnik po istorii administrativno-territorial'nogo deleniya Severo-Kazahstanskoj oblasti [Spravochnik] (2007). (29.07.193601.01.2007), [Handbook on the history of the administrative-territorial division of the North Kazakhstan region (29.07.193601.01.2007)]. Petropavlovsk, 361, (in Kazakh), Accessed 30.05.2021, Electronic resource. https://elib.skolib.kz/catalog/item386.html

Article history: Received: 15.06.2021 Revised: 14.08.2021 Accepted: 24.09.2021 Available online: 20.10.2021 